Permits will be necessary for those who wish to undertake research, to collect specimens, or to visit areas away from the rights of way. Applications for permits should be sent to the Regional Officer for North Wales, in Caernarvon.

Coed Gorswen Nature Reserve, lying at the northern end of the Conway Valley on the western side of the river near Rowen, is a good example of a lowland oak wood. The reserve, which covers 33 acres of the woodland and lies within the Snowdonia National Park, has been established under leases with the owners of the land.

The subsoil of Coed Gorswen is a very bouldery glacial drift and probably as a consequence of this it has been woodland for a very long time, perhaps throughout the historical period. The oaks consists of a heterogeneous population of intermediate forms between the sessile and pedunculate oak. As well as oak, other trees present in some quantity include elm, ash and alder. The ground flora is typical of rather base-rich soils, including such species as dog's mercury, sanicle, slender false-brome, common enchanter's night-shade, broad helliborine, skull cap and very locally yellow archangel. Fringing the wood is some interesting fenny ground-no doubt the "gors wen" (white marsh) which gave the wood its name-dominated by purple moor-grass with associates such as quaking grass.

Permits, which will be required to visit parts of the reserve away from the rights of way, to collect specimens of animals or plants, or to undertake research, can be obtained from the Regional Officer for North Wales.

Allt Rhyd-y-groes Nature Reserve is situated in the valley of the Afon Doethie, a tributary of the Towy, about nine miles north of Llandovery in Carmarthenshire. The reserve consists of 46 acres of oak woodland and has been leased to the Nature Conservancy by the Earl of Cawdor. It is hoped that it will ultimately be extended to include other areas of out. standing scientific interest in the locality.

The reserve overlies shales of Silurian age, and extends between 500 and $1,000 \mathrm{ft}$. on the west side of the steep flanks of the Doethie Valley. The wood- lands are dominated by the sessile oak, as is the Coed Rheidol Nature Reserve in Cardiganshire, but here at Allt Rhyd-y-groes a number of the trees are well grown and display a vigour which is not often seen in equivalent woods elsewhere in Wales. The drier, more eroded slopes are clothed in sweet vernal grass together with mosses at the lower levels, and sheep's fescue higher up the slope.

Permits to visit parts of the reserve away from the rights of way, to collect specimens of animals or plants or to undertake research, can be obtained from the Regional Officer for South Wales, The Nature Conservancy, c/o Department of Zoology, University College of Swansea, Singleton Park, Swansea.

Blackcliff and Wyndcliff Forest Nature Reserve. An agreoment has recently been reached between the Nature Conservancy and the Forestry Commission on the management of approximately 200 acres of Blackeliff and Wyndeliff Woods, forming part of the Commission's Tintern Forest, Monmouthshire, as a Forest Nature Reserve in the interest of nature conservation and ecological research jointly with those of timber production. The high amenity value of the area, which is close to Tintern Abbey and within the Forest of Dean Forest Park, will be maintained. These woods, situated on the Carboniferous limestone of the Wye Valley, have long been regarded by botanists as being of outstanding scientific interest; they were visited by John Ray in 1662 and by Sir Joseph Banks and John Lightfoot in 1773. The steep slopes are finely wooded with ash, wych elm, beech, small-leaved lime, yew, oak, cherry and whitebeam and service tree, together with a number of shrubs including dogwood, guelder rose and spurge laurel. The ground flora is rich and includes some locally uncommon species : lily of the valley is found there, and white angular Solomon's seal occurs on the cliffs.

Access will be unrestricted, but permits will be required to collect specimens of animals or plants, or to undertake research. Applications for permits should be sent to the Regional Officer for South Wales at the University College of Swansea.

\title{
INVESTMENT IN THE COAL, ELECTRICITY AND GAS INDUSTRIES
}

T replying for the Government in a debate on fuel 1 and power policy in the House of Commons on February 6, the Parliamentary Secretary to the Ministry of Power, Sir Ian Horobin, said that the oil companies and the Central Electricity Generating Board were considering together whether, within the framework of existing contracts, it would be practicable to postpone the conversion of two more power stations to oil during 1959; even in the changed industrial climate of the past twelve months Sir Ian said it would be wrong and improper to break contract or use pressure to that end. In moving the second reading of the Electricity (Borrowing Powers) Bill on January 20, the Paymaster-General, Mr. R. Maudling, said that the purpose of the Bill was to increase the authorized capital of the industry under the Bill, and the Electricity Council's permitted borrowings would be increased to $£ 2,300$ million, those of the North of Scotland Hydroelectric Board to $£ 300$ million and of the South of Scotland Electricity Board to £135 million. The total capital investment of the industry envisaged over the next seven years amounted to $£ 2,130$ million, of which $£ 1,470$ million would be in generation and $£ 660$ million in distribution : these figures were for the Electricity Council alone. This plan was based on estimated demand for electricity over the period, including a two-thirds increase in consumption, in which farm uses would be doubled and other commercial use would increase by about 50 per cent, or an annual increase of $6 \cdot 6$ per cent compared with $7 \cdot 6$ per cent in the past seven years. To meet this estimated increased demand of just under 9 million kilowatts, new plants for $12 \cdot 25$ kilowatts would be commissioned. The load factor had improved from $42 \cdot 7$ per cent in 1947 to $46 \cdot 8$ per cent in 1958 compared with a probable maximum of 60 per cent, and the problem of increasing the factor was being tackled with vigour. The cost per kilowatt 
of increased capacity was now no higher than ten years ago, in spite of the increase in cost of materials and labour. As regards nuclear power, the cost of the Bradwell and Berkeley stations would be about three times that of a coal-fired station, but that of Hinkley Point should be about 2.5 times, and it was now calculated that this would be about $£ 120$ a kilowatt. By the nineteen-sixties the nuclear plant should be marginally more economical than conventional plant. There had already been a reduction at the rate of about 3 million tons of coal a year in the amount of oil to be used for power stations in the early nineteen-sixties, and the Government believed that the demand of the power stations for coal would rise throughout the next seven years.

Lord Mills, the Minister of Power, added a few further details in moving the second reading of the Bill in the House of Lords on March 3. Since some of the existing plant will not be fully operated, and because of obsolescence, the net increase in output capacity in England and Wales will be just over 10 million kilowatts, while the South of Scotland Electricity Board expects to commission more than 1 million kilowatts of new plant and the North of Scotland Hydroelectric Board about 460,000. The load factor is expected to increase to $49 \cdot 2$ per cent by 1964-65, and Lord Mills hoped that substantial improvements could be made in the methods of transmission and distribution so as to reduce the need for overhead lines in the countryside. The Boards had very much in mind the need to find means of diminishing the impact of their lines on amenities. Apart from the hydroelectric plant in the north of Scotland, practically all this new plant would be coal-fired or nuclear, and it was estimated that nuclear power could absorb nearly 47 per cent of the $£ 1,100$ million which the Central Electricity Board proposed to spend on power station construction. The nuclear power programme for 1964 onwards had not yet been decided, but apart from water-power we intended to rely in the long-term on coal and on nuclear power : less than 4 per cent of the investment in power stations proposed over the next seven years represented oil-fired plant.

These statements form a background to the third White Paper* on capital investment in the coal, electricity and gas industries, which is limited to the years 1957-59. Actual expenditure in 1957 was $£ 434.7$ million, compared with $£ 438.9$ million and $£ 524.7$ million approved for 1958 and 1959 , respectively. Of these figures, $£ 240 \cdot 2$ million, $£ 241 \cdot 3$ million and $£ 303.5$ million are for the Electricity Council and Boards in the respective years: actual expenditure in $\mathbf{1 9 5 8 - 5 9}$ is estimated to have been $£ 258.5$ million, of which $£ 106.5$ million was for conventional power stations and $£ 38 \cdot 0$ million for nuclear power stations. The corresponding figures in the approved 1959-60 programme are $£ 117.5$ million and $£ 57.0$ million, and payments in respect of the nuclear power stations at Bradwell, Berkeley and Hinkley Point will reach their peak during the year. The North of Scotland Hydroelectric Board's programme of capital expenditure of $£ 10$ million on generation for 1959 is mainly for hydroelectric schemes at present in hand, while that of the South of Scotland Electricity Board of $\mathfrak{£} 16.2$ million on generation in 1959 is almost entirely accounted for by the nuclear power station at Hunterston and the coal-fired station at Kincardine.

* Capital Investment in the Coal, Electricity and Gas Industries.

\section{BATHYSCAPHE F.N.R.S. III}

$\mathrm{O}$ $\mathrm{NE}$ of the greatest recent advances in methods of deep-sea research is that of direct observation under water by photography, television and the human eye. The latter had already been shown possible before the Second World War by Otis Barton and William Beebe in the cable-dependent bathysphere.

In 1939, Prof. Auguste Piccard and Prof. Max Cosyns gained the support of the Fonds National de la Recherche Scientifique Belge (F.N.R.S.) to build their free-navigating bathyscaphe, but owing to the War its construction was delayed. The first tests were made in December 1948 off Dakar in the vessel which was entitled F.N.R.S. II, the Piccard-Cosyns stratosphere balloon being F.N.R.S. I. A depth of $1,380 \mathrm{~m}$. was achieved without passengers. Although improvements were needed, the possibilities of the bathyscaphe were proved, and in October 1950 an agreement was signed between the Belgian Fonds National de la Recherche Scientifique, the French Navy, and the French Centre National de la Recherche Scientifique for the construction by the French Navy at Toulon of F.N.R.S. III, using the sphere of bathyscaphe F.N.R.S. II. This new vessel was put into the water in June 1953 and Capitaine de corvette G. Houot was placed in command with Ingénieur du génie maritime P. Willm to assist. Together they carried out a series of tests ending off Dakar in February 1954 when they reached a depth of $4,050 \mathrm{~m}$.
In May 1954 the French Centre National de la Recherche Scientifique obtained permission from the Navy to equip and use F.N.R.S. III for scientific purposes. A management committee was appointed under the stimulating presidency of Prof. Louis Fage. The first dive was made on April 18, 1954, at a position 25 miles south-west of Dakar to a depth of $850 \mathrm{~m}$. with Prof. Th. Monod as the scientist on board; this was quickly followed by a dive to 1,400 $m$. Thereafter a certain number of dives have been made each year with Commandant Houot on board, accompanied by a qualified naturalist. By the end of 1957, twenty-eight dives had been made to depths between $130 \mathrm{~m}$. and $2,290 \mathrm{~m}$., eighteen of which were deeper than 1,000 m. Eight distinguished and courageous biologists took part. Their names are given here, together with the number of dives each made, because they should be remembered as pioneers of this new era of marine research : Prof. Th. Monod, Dakar (2); Prof. J.-M. Péres, Marseilles (9); J. Picard, Marseilles (4) ; Prof. Fr. Bernard, Algiers (3) ; J. Furnestin, Paris (1); Prof. Dubuisson, Liège (1); G. Trégouboff, Villefranche (6) ; M. Ruivo, Lisbon (1).

Dives were made in the Mediterranean and the Atlantic. F.N.R.S. III is equipped with apparatus for recording at any time the depth, temperature and pressure; it has equipment for collecting water samples with contained microplankton; and it has powerful light projectors and automatic cameras. It 